\title{
DISPROPORTIONS \\ IN PROPORTIONAL DISTRIBUTIONS
}

\begin{abstract}
Andrzej Misztal
Abstract. In the case of degressive proportionality, a large over-representation of small countries is a deliberate concession of larger countries to ensure that less populated states are adequately represented (the principle of European solidarity). It is worth emphasizing how important is the role played by election thresholds, which prevent excessive fragmentation of the parliament. Thus, they act as a stabilizing factor in the political scene, which in Polish conditions cannot be overestimated. A weakness of the thresholds is the fact that they distort the proportionality of the results and cause over-representation of certain parties. In extreme cases they can lead to the dictatorship of one party even if it is provided with low popularl support.
\end{abstract}

Keywords: electoral threshold, degressive proportionality, over-representation, proportionality.

JEL Classification: C25.

DOI: $10.15611 / \mathrm{me} .2013 .9 .07$.

\section{Introduction}

In practice, the rules of allocation of goods generally boil down to one of the three concepts of justice. Equality, where each participant of the division is to be considered in the same way. Priority, which requires the granting of goods to a specific person who for some reason should be given precedence. Finally, as already advocated by Aristotle, proportionality, which means that participants are differentiated, and goods are to be distributed proportionally to those differences. A classic problem of this type are proportional methods of allocating seats in electoral systems used by many democratic countries, including Poland (Lijphart 2000). It is worth noting that, for various reasons, a partial violation of the principle of proportionality is applied (Gallagher 1991). Interestingly those changes are supported by appropriate legal acts. One should also consider how big disproportions they

\footnotetext{
Andrzej Misztal

Department of Quantitative Methods in Economics, Wrocław University of Economics, Komandorska Street 118/120, 53-345 Wrocław, Poland.

E-mail: andrzej.misztal@ue.wroc.pl
} 
can cause. In the case of elections to national parliaments, to avoid excessive fragmentation of the parliament, a legal election threshold (Rae, Hanby, Loosenmore 1971; Taagepera 1998) is often used, which is the minimum level of votes collected at national level necessary to obtain a mandate for the group, thus eliminating from the distribution the weakest parties which have failed to reach this threshold. In the case of elections to the European Parliament, it was proposed in the Lisbon Treaty to use instead of the ordinary proportionality, the so-called degressive proportionality which assigns more populous countries with less seats than would result from an ordinary proportion.

\section{The maximum over-representation for proportional distribution}

We introduce the following notations:

$p \in(0,1)$ - electoral threshold expressed for convenience as a number, $M$ - total number of seats to gain,

$X_{1}, \ldots, X_{m}$ - the number of votes won by parties which have reached the electoral threshold:

$X=X_{1}+\ldots+X_{m}$

$N$ - total votes cast on all parties;

$S_{j}$ - overrepresentation $j$ - party understood as the ratio of the number of seats gained by it thanks to the introduction of the election threshold and the number of seats that would have been gained if the threshold had not been applied. For simplicity we do not include here roundings resulting from the fact that the number of seats is an integer. We do not take into account the possible distortions of the proportions resulting from the distribution of seats at the level of constituencies. Therefore, the number of seats gained by $j$-party is:

with no threshold

$$
\begin{gathered}
\frac{M X_{j}}{N}, \\
\frac{M X_{j}}{X} .
\end{gathered}
$$

with a threshold

By definition of the number $X$ we may estimate its value: $X \geq m p N$. After taking this inequality into account we obtain the maximum value of over-representation:

$$
S_{j}=\frac{\frac{M X_{j}}{X}}{\frac{M X_{j}}{N}}=\frac{N}{X} \leq \frac{1}{m p} \leq \frac{1}{p} .
$$


This is $\frac{1}{m p}$ in cases when $m$ parties exceeded the election threshold. If only one party has achieved such a goal, its over-representation is $\frac{1}{p}$.

Currently in Poland there is a 5\% barrier clause, thus $p=0.05$. Let us consider a theoretical situation in which 21 political parties compete in elections to the Polish Parliament. These are the results of the polls:

Party A got $5 \%$ of votes, parties $B_{1}, \ldots, B_{19}$ got $4.95 \%$ of votes each, and party $B_{20}$ got $0.95 \%$ of votes. Because only party $A$ managed to obtain the election threshold it received $100 \%$ of the seats. Thus its over-representation equals $100 / 5=20$.

\section{Statutory election thresholds}

The height of the thresholds is different in different countries. For example, in Poland, Slovakia, and Romania it is 5\% (see Art. 133 Electoral Law to the Sejm (lower house of the Polish Parliament) of 2001). In Austria, Italy, Bulgaria $-4 \%$. Greece and Spain have a three percent threshold, Albania $-2.5 \%$, and Denmark - $2 \%$.

Introduction of the barrier clause in Poland was a reaction to the results of the first fully free parliamentary elections in postwar Poland in 1991. The elections were conducted in 37 constituencies, where 391 seats were distributed. The remaining 69 seats were filled from national lists. Seats in electoral districts were allocated according to the proportional method of Hare-Niemeyer and the seats from the national lists were distributed with the use of a revised method of Sainte-Laguë (Banaszak, Preisner 1992). These could be obtained by the electoral committees which received at least $5 \%$ of valid votes at national level or won seats in at least five constituencies. Out of the 111 registered election committees, mandates were obtained by as many as 29 , which was caused by the lack of an election threshold in selecting members from the regional lists. This led to an excessive fragmentation of Parliament and thus the inability to create a lasting coalition government and early elections in 1993.

The use of the barrier clause will sometimes cause a large overrepresentation of parties that entered parliament because they gained the votes cast for those parties who failed to reach the required minimum. In Poland after the elections of 1993 it turned out that the parties which did not enter parliament obtained a total of $34.7 \%$ of the votes. This resulted in the 
fact that two winning groups, SLD (Democratic Left Alliance) and PSL (Polish Peasant Party), although having obtained only $35.8 \%$ of votes won a total of $65.9 \%$ of seats (303 of 460), which allowed them to create a majority coalition. If the electoral threshold had not been in force, the SLD-PSL coalition would have won only 173 seats (Kaminski, Gryz 1997). The reaction of voters in the following elections to the Sejm in 1997 was "wasting" only $12.4 \%$ of votes for parties that did not reach the level of $5 \%$. In the case of the two largest groups, AWS and SLD, the level of overrepresentation, understood as the percentage excess this time was "only" $18.6 \%$ (instead of $30 \%$ previously), which still shows the large impact of the election threshold on election results. In Poland in the period 1991-2000 we could observe the extra reinforcement of large parties resulting from the use of the national list (69 seats) apart from the district lists (a total of 391 seats). A voter who had one vote at his/her disposal, cast a vote on the district list and at the same time on the country list. This increased the pool of the received seats, because in order to participate in the distribution of seats from the national list, it was necessary to reach the threshold of $7 \%$. Since 2001, all the 460 deputies have been elected in constituencies, as the institution of national lists was removed. In the election of 2001the modified method of Sainte-Laguë was used for the last time because since 2005 parliamentary seats have been allocated using only D'Hondt's method. Because of the small number of electoral committees the effect of the overrepresentation of the large parties in 2001 was not as big as in previous years. The SLD (Democratic Left Alliance)-UP (Labour Union) coalition was around $6 \%$, for the PO (Civic Platform) only $1.4 \%$ and $1.3 \%$ for Samoobrona (Self-Defense). In turn, in 2005, the over-represented parties were: PiS (Law and Justice) - about 6.7\%, PO (Civic Platform) - about $3.9 \%$, Samoobrona (Self-Defense) - approximately $0.8 \%$ and SLD (Democratic Left Alliance) - about $0.7 \%$. PiS (Law and Justice) formed a coalition government, Samoobrona (Self -Defense) and LPR (League of Polish Families), which together received $46.37 \%$ of votes and 245 seats (i.e. 53.26\%). This small advantage was only enough for two years of rule and led to early elections in 2007. The detailed results are presented in Table 1. 
Table 1. Results of the elections to the Polish Sejm in 2007

\begin{tabular}{|c|c|c|c|c|}
\hline Electoral committee & Votes & $\begin{array}{c}\% \\
\text { of votes }\end{array}$ & Seats & $\begin{array}{c}\% \\
\text { of seats }\end{array}$ \\
\hline $\begin{array}{l}\text { Platforma Obywatelska RP } \\
\text { (Civic Platform) }\end{array}$ & 6701010 & 41,51 & 209 & 45,43 \\
\hline $\begin{array}{l}\text { Prawo i Sprawiedliwość } \\
\text { (Law and Justice) }\end{array}$ & 5183477 & 32,11 & 166 & 36,09 \\
\hline $\begin{array}{l}\text { Lewica i Demokraci } \\
\text { (The Left and Democrats) }\end{array}$ & 2122981 & 13,15 & 53 & 11,52 \\
\hline $\begin{array}{l}\text { Polskie Stronnictwo Ludowe } \\
\text { (Polish Peasant Party) }\end{array}$ & 1437638 & 8,91 & 31 & 6,74 \\
\hline $\begin{array}{l}\text { Samoobrona RP } \\
\text { (Self-Defense) }\end{array}$ & 247335 & 1,53 & - & - \\
\hline $\begin{array}{l}\text { Liga Polskich Rodzin } \\
\text { (League of Polish Families) }\end{array}$ & 209171 & 1,30 & - & - \\
\hline $\begin{array}{l}\text { Polska Partia Pracy } \\
\text { (Polish Labour Party) }\end{array}$ & 160476 & 0,99 & - & - \\
\hline $\begin{array}{l}\text { Partia Kobiet } \\
\text { (Women's Party) }\end{array}$ & 45121 & 0,28 & - & - \\
\hline $\begin{array}{l}\text { Mniejszość Niemiecka } \\
\text { (German Minority) }\end{array}$ & 32462 & 0,22 & 1 & 0,22 \\
\hline $\begin{array}{l}\text { Samoobrona Patriotyczna } \\
\text { (Patriotic Self-Defense) }\end{array}$ & 2531 & 0,02 & - & - \\
\hline Other committees & 191672 & 1,17 & - & - \\
\hline Total & 16333874 & 100 & 460 & 100 \\
\hline
\end{tabular}

Source: National Election Commission (PKW).

Table 2 shows simulation results of the elections, if the seats had been allocated using the methods of Sainte-Laguë or Hare-Niemeyer.

In each case, the PO (Civic Platform) and PiS (Law and Justice) are overrepresented in relation to the votes obtained, the allocation is most preferable for them when the method of D'Hondta is used. 
Table 2. Simulation results of the elections to the Polish Sejm in 2007, with the methods of Sainte-Laguë and the Hare-Niemeyer

\begin{tabular}{|c|c|c|c|c|c|c|}
\hline Electoral committee & Votes & $\begin{array}{l}\% \text { of } \\
\text { votes }\end{array}$ & $\begin{array}{c}\text { Seats } \\
\text { Sainte-L }\end{array}$ & $\begin{array}{c}\% \text { of } \\
\text { seats } \\
\text { Sainte-L }\end{array}$ & $\begin{array}{l}\text { Seats } \\
\text { Hare-N }\end{array}$ & $\begin{array}{c}\% \text { of } \\
\text { seats } \\
\text { Hare-N }\end{array}$ \\
\hline $\begin{array}{l}\text { Platforma Obywatelska RP } \\
\text { (Civic Platform) }\end{array}$ & 6701010 & 41,51 & 195 & 42,39 & 195 & 42,39 \\
\hline $\begin{array}{l}\text { Prawo i Sprawiedliwość } \\
\text { (Law and Justice) }\end{array}$ & 5183477 & 32,11 & 155 & 33,70 & 155 & 33,70 \\
\hline $\begin{array}{l}\text { Lewica i Demokraci } \\
\text { (The Left and Democrats) }\end{array}$ & 2122981 & 13,15 & 60 & 13,04 & 59 & 12,83 \\
\hline $\begin{array}{l}\text { Polskie Stronnictwo Ludowe } \\
\text { (Polish Peasant Party) }\end{array}$ & 1437638 & 8,91 & 49 & 10,65 & 50 & 10,87 \\
\hline $\begin{array}{l}\text { Samoobrona RP } \\
\text { (Self-Defense) }\end{array}$ & 247335 & 1,53 & - & - & - & - \\
\hline $\begin{array}{l}\text { Liga Polskich Rodzin } \\
\text { (League of Polish Families) }\end{array}$ & 209171 & 1,30 & - & - & - & - \\
\hline $\begin{array}{l}\text { Polska Partia Pracy } \\
\text { (Polish Labour Party) }\end{array}$ & 160476 & 0,99 & - & - & - & - \\
\hline $\begin{array}{l}\text { Partia Kobiet } \\
\text { (Women's Party) }\end{array}$ & 45121 & 0,28 & - & - & - & - \\
\hline $\begin{array}{l}\text { Mniejszość Niemiecka } \\
\text { (German Minority) }\end{array}$ & 32462 & 0,22 & 1 & 0,22 & 1 & 0,22 \\
\hline $\begin{array}{l}\text { Samoobrona Patriotyczna } \\
\text { (Patriotic Self-Defense) }\end{array}$ & 2531 & 0,02 & - & - & - & - \\
\hline Other committees & 191672 & 1,17 & - & - & - & - \\
\hline Total & 16333874 & 100 & 460 & 100 & 460 & 100 \\
\hline
\end{tabular}

Source: National Election Commission (PKW).

The precise way the distribution of seats by D'Hondt's formula is described in Article 166 paragraph 1 and 2 of the Act of 12 April 2001 Elections to the Polish Sejm and the Polish Senate (Journal of Laws of 2007 No 190, pos. 1360 as amended). It is as follows:

1) number of votes validly cast for each of the list in the electoral constituency shall be divided successively by 1, 2, 3, 4 and so on up to the point when from the quotients thus obtained it is possible to establish a sequence of as many successively highest numbers as there are seats to be allocated among the lists;

2) to each list shall be allotted as many seats as it has received highest consecutive numbers attributed by the sequence of quotients obtained in the manner prescribed above. 
The method of the distribution of seats according to the method of Sainte-Laguë was described in the original version of art. Paragraph 166. 1 and 2 of the Election to the Sejm and the Senate of 12 April 2001. It is different from D'Hondt's method only in that the number of votes are divided not by all the natural numbers, and only the odd $(1,3,5,7, \ldots)$.

The method of calculating the results of elections in constituencies by Hare-Niemeyer is described already in the non-binding act of June 8, 1991 Elections to the Polish Sejm [Journal of Laws No. 59, item. 252]. In Article 93, paragraphs 1 and 2 of the Act provide the following procedure for the distribution of seats in constituencies:

1) the number of valid votes in the constituency cast for each list is multiplied by the number of members of parliament elected in the constituency, then the resulting product is divided by the number of votes cast for all electoral lists. The resulting integer quotient (before the comma) is the number of seats allocated in a given constituency to a given list of candidates;

2) if, after performing the above procedure sequentially in all electoral lists all seats are not allocated, the remaining seats are to be assigned to those lists for which the calculated quotients showed "after a comma" the next highest values, taking into account also the lists that have not received any mandate.

\section{The donation paradox}

One should also mention the so-called donation paradox that occurs when one performs a "transfer" of votes to another party's list, and which results in an additional mandate for the "donor". This is possible thanks to the use of electoral thresholds. One can imagine a situation where a small part of the group urges its voters to vote for the opponent to bring about the effect of donations, and thus gain an additional seat.

Table 3. The donation paradox (distribution of 24 seats with the largest remainder method)

\begin{tabular}{|c|c|c|c|c|c|c|}
\hline $\begin{array}{c}\text { Electoral } \\
\text { list }\end{array}$ & $\begin{array}{c}\text { Number } \\
\text { of votes }\end{array}$ & $\begin{array}{c}\text { Number } \\
\text { of quotas }\end{array}$ & $\begin{array}{c}\text { Number } \\
\text { of seats }\end{array}$ & $\begin{array}{c}\text { Number } \\
\text { of votes }\end{array}$ & $\begin{array}{c}\text { Number } \\
\text { of quotas }\end{array}$ & $\begin{array}{c}\text { Number } \\
\text { of seats }\end{array}$ \\
\hline A & 4245 & 10,72 & $10+1=11$ & 4245 & 10,19 & $10+0=10$ \\
\hline B & 2575 & 6,51 & $6+1=7$ & 2575 & 6,18 & $6+0=6$ \\
\hline C & 2160 & 5,46 & $5+0=5$ & 2160 & 5,18 & $5+0=5$ \\
\hline D & 521 & 1,32 & $1+0=1$ & 520 & 1,25 & $1+1=2$ \\
\hline E & 499 & $\mathrm{E}<5 \%$ & 0 & 500 & 1,20 & $1+0=1$ \\
\hline Total & 10000 & - & 24 & 10000 & - & 24 \\
\hline
\end{tabular}

Source: own elaboration based on (Haman 2000). 
Quota methods are susceptible to this paradox, the best known of which is the largest remainder method by Hare-Niemeyer. In Table 3, the list E in the first version did not reach the five-percent threshold, and thus received no mandate. In the second version (thanks to one vote received at the expense of list D) list E gains a seat, while at the same time allowing list $\mathrm{D}$ to gain an additional seat.

\section{The principle of degressive proportionality as a method of allocating seats in the European Parliament}

Initially, members of the European Parliament were elected by parliaments of the Member States. In 1976 the "Act concerning the election of Members of the European Parliament" was created, which meant that since 1979 they have been elected in direct universal elections. At the European Council in 1976 the composition of Parliament was established for the purpose of the first elections of such a kind. According to it, the four largest countries Great Britain, the Federal Republic of Germany, France and Italy received 81 seats each, the Netherlands -25 seats, Belgium - 24 seats, Denmark - 16 seats, Ireland - 15 seats, Luxembourg - 6 seats. In the division of seats for smaller countries the following principle was used: the number of members was in proportion to the population of the country they represented, but higher than the proportion of the population in the sum of all the citizens of the European Economic Community. The first changes in the composition of Parliament occurred in 1981, when Greece joined the European Community, and next in 1986 a year after with the integration of Spain and Portugal. For the new members, new seats were created by the same rule which was applied in 1979. As a result, Greece and Portugal were given 24 seats each, and Spain 60 seats. At this point, the Parliament already numbered 518 people. The allocation of seats was as follows: Federal Republic of Germany, France, Great Britain, Italy - 81 seats each, Spain - 60, the Netherlands -25 , Belgium, Greece and Portugal -24 , Denmark -16 , Ireland -15 , Luxembourg - 6. After the reunification of Germany, from 1 January 1994 the total number of seats was 567, and a year later that figure was enlarged to 626 seats after the accession of Sweden, Austria and Finland. The following Member States gained additional seats: Germany - 18, France and Sweden - 22, Italy and Austria - 21, Finland - 16, the Netherlands and the United Kingdom - 6, Spain - 4, and Belgium, Greece and Portugal -1 seat. At the same time a new model was provided according to which each Member State received six seats. In addition, one seat for every 
500000 of residents was appointed to countries whose populations ranged from 1 to 25 million. Then, one seat for every million citizens was given to countries with a population of 25 to 60 million. Finally, the state, whose population exceeded 60 million got one seat for each additional 2 million people (Cegiełka, Dniestrzański, Łyko, Misztal 2010b). The above formula was written in the Treaty of Amsterdam, which also reduced the number of deputies to seven hundred. The first rule of determining the exact composition of the European Parliament therefore, was not based on the principle of proportionality, that is, representing by each MP the same number of citizens. This was due to significant differences in the populations of the Member States. Thus the parliamentarians of larger countries represent more citizens than their counterparts from smaller Member states.

Further adjustments were made in the Treaty of Nice in the face of EU enlargement to include ten more countries. It increased the total number of Members of the European Parliament to 732. A Government Conference in Nice introduced new rules for the allocation of seats in Parliament that were used during the elections in 2004. Citizens of 25 countries elected 732 representatives. The number of deputies elected in countries with a longer period in the EU was reduced by allocating part of the votes to newcomers. As a result, Spain lost 10 seats, France Italy and the UK - 9, Netherlands 4, Austria and Sweden - 3, Denmark, Finland and Ireland - 2, Belgium, Greece and Portugal - 1 .

In 2007 the number of seats in the European Parliament was temporarily increased to 785 members in order to accept MPs from two new countries: Bulgaria and Romania, which received 35 and 18 seats respectively.

The rapid development of the European Union at the turn of the $21^{\text {st }}$ century, the accession of additional members, and the prospect of further expansion, necessitated the introduction of strict regulations on the number of MPs and the creation of an algorithm thanks to which it would be possible to determine the size of representation of the Member States. The legal framework in this area is contained in the Treaty establishing a Constitution for Europe (2004) and the Lisbon Treaty signed on 13 December 2007 and ratified by the recent Members of the Union at the end of 2009. Crucial for the next term of Parliament is Article 1 of the Lisbon Treaty (Sosnowski 2008). 


\section{Article 1 of the Lisbon Treaty}

15) An article 9 a shall be inserted

"Article 9 a

1. The European Parliament shall, jointly with the Council, exercise legislative and budgetary functions. It shall exercise functions of political control and consultation as laid down in the Treaties. It shall elect the President of the Commission.

2. The European Parliament shall be composed of representatives of the Union's citizens. They shall not exceed seven hundred and fifty in number. Representation of citizens shall be degressively proportional, with a minimum threshold of six members per Member State. No Member State shall be allocated more than ninety-six seats.

The European Council shall adopt by unanimity, on the initiative of the European Parliament and with its consent, a decision establishing the composition of the European Parliament, respecting the principles referred to in the first subparagraph.

3. The members of the European Parliament shall be elected for a term of five years by direct universal suffrage in a free and secret ballot.

In 2007 the European Council turned to the European Parliament to prepare a draft of a new distribution of seats in Parliament based on the principles adopted in the Lisbon Treaty, which at that time was not legally binding. The Committee on Constitutional Affairs, which was entrusted with this task, presented on $3^{\text {rd }}$ October a report in which it included a project of the proper resolution of the European Parliament. The resolution was adopted during a meeting of Parliament on $11^{\text {th }}$ October 2007. In support of the report, six principles were presented which, according to the Committee on Constitutional Affairs, could clarify the rule of degressive proportionality:

\section{Principle 1. The principle of effectiveness}

- the functioning of the European Parliament is impossible if its composition exceeds the specific number of deputies - hence the restriction of 750 members.

Principle 2. The principle of national representation and the motivation of the voters

- each Member State should have the minimum number of seats, so it will be able to represent their electorate by motivating them to participate in the elections. 


\section{Principle 3. The principle of European solidarity}

- in order to ensure adequate representation of less populous States, countries with a greater number of citizens will receive fewer seats than in the case of the application of the principle of ordinary proportionality.

\section{Principle 4. The principle of relative proportionality}

- the ratio between the number of population and the number of seats increases along with their increase in the State.

\section{Principle 5. The principle of fair distribution}

- no State will have more seats than a larger Member State or a smaller amount of seats than a smaller Member State.

\section{Principle 6. The principle of reasonable flexibility}

- small changes to the allocation of seats may be implemented if other principles are obeyed and the modification aims at the most equitable distribution of seats.

In addition, measures were determined by means of which it is verified if the set up composition reflects in the best way the structure of the European Union. These are:

- ratio population/Members of Parliament - according to the principle of degressive proportionality, an MP from a Member State with a large population represents more citizens than an MP from a smaller State. So the more populous country, the greater the ratio.

- ratio between the share of a Member State's citizens in the population of the European Union and the share of seats allocated to that country in the total number of parliamentarians - should decrease with the increase of population.

However, despite the general definition of the rule of degressive proportionality and placing it in such an important document, no exact formula or algorithm specifying its use was given. According to A. Lamassoure and A. Severin - Rapporteurs in the conference on the composition of the European Parliament in 2007 - mathematical analyses of the various proposed formulas were carried out. It was, however, stated that each model is the successor of certain political conditions and thus would favor some countries over others. It was also considered whether to continue the 1992 rule, or its modification, but this was considered not completely fair, because it would favour countries with an average population density. The distribution of seats in parliament is thus always negotiated by Member States. It is worth noting that from point 1 of Article 9a of the Lisbon Treaty it can be 
seen that the number of all the deputies in the European Parliament may amount to $\mathbf{7 5 1}$, i.e. 750 Members of Parliament and one non-voting chairman.

\section{Current composition of the European Parliament}

The composition of Parliament for the term 2009-2014 was not selected according to the principle of degressive proportionality. This is because the Lisbon Treaty came into force on 1 December 2009, hence it was not in force during the elections in June 2009. The allocation of seats in Parliament in its seventh term remained unchanged in relation to the distribution under the Treaty of Nice. The only difference is the additional need for two seats for the Czech Republic and Hungary, thus setting the total number of deputies to 736. The distribution of seats in the European Parliament for the term 2009-2014 is shown in Table 4.

Problems with the ratification of the Lisbon Treaty caused the postponement of the practical application of the principle of degressive proportionality. This rule, however, was included in the proposal from 2007 showing the proposed composition of Parliament for the period 2009-2014. The project, unrealized in practice, is presented in Table 5.

Early ratification of the Lisbon Treaty by all Member States would change the current composition of Parliament. The proposed allocation of seats included in the report of the Constitutional Affairs Committee, prepared by the Rapporteurs Alain Lamassoure and Adrian Severin (2007) meet the principle of degressive proportionality - along with the increase of population the ratio population/Member States grows too (the last column of Table 5). Comparing the columns of Table 5 that contain $\%$ of population, $\%$ of seats in the EP, one can discern that the most populous EU countries, namely Germany, France, Great Britain, Italy, Spain and Poland are underrepresented. These factors are: $0.77,0.77,0.79,0.81,0.81$ and 0.88 respectively. The countries with smaller populations, such as Malta and Luxembourg, are over-represented in the relations of 8 and 10, respectively. 
Table 4. The composition of the EP in 2009-2014

\begin{tabular}{|c|c|c|c|c|}
\hline $\begin{array}{c}\text { Member } \\
\text { State }\end{array}$ & $\begin{array}{c}\text { Population } \\
\text { (millions) }\end{array}$ & $\begin{array}{l}\text { Number of } \\
\text { seats in EP }\end{array}$ & $\begin{array}{l}\text { Share of the State's } \\
\text { population in the } \\
\text { population of EU }\end{array}$ & $\begin{array}{c}\text { Share of the State's } \\
\text { seats in the total } \\
\text { number of seats }\end{array}$ \\
\hline Germany & 82.438 & 99 & $16.72 \%$ & $13.45 \%$ \\
\hline France & 62.999 & 72 & $12.78 \%$ & $9.78 \%$ \\
\hline Great Britain & 60.393 & 72 & $12.25 \%$ & $9.78 \%$ \\
\hline Italy & 58.752 & 72 & $11.92 \%$ & $9.78 \%$ \\
\hline Spain & 43.758 & 50 & $8.88 \%$ & $6.79 \%$ \\
\hline Poland & 38.157 & 50 & $7.74 \%$ & $6.79 \%$ \\
\hline Romania & 21.610 & 33 & $4.38 \%$ & $4.48 \%$ \\
\hline Holland & 16.334 & 25 & $3.31 \%$ & $3.40 \%$ \\
\hline Greece & 11.125 & 22 & $2.26 \%$ & $2.99 \%$ \\
\hline Portugal & 10.570 & 22 & $2.14 \%$ & $2.99 \%$ \\
\hline Belgium & 10.511 & 22 & $2.13 \%$ & $2.99 \%$ \\
\hline Czech Republic & 10.251 & 22 & $2.08 \%$ & $2.99 \%$ \\
\hline Hungary & 10.077 & 22 & $2.04 \%$ & $2.99 \%$ \\
\hline Sweden & 9.048 & 18 & $1.84 \%$ & $2.45 \%$ \\
\hline Austria & 8.266 & 17 & $1.68 \%$ & $2.31 \%$ \\
\hline Bulgaria & 7.719 & 17 & $1.57 \%$ & $2.31 \%$ \\
\hline Denmark & 5.427 & 13 & $1.10 \%$ & $1.77 \%$ \\
\hline Slovakia & 5.389 & 13 & $1.09 \%$ & $1.77 \%$ \\
\hline Finland & 5.256 & 13 & $1.07 \%$ & $1.77 \%$ \\
\hline Ireland & 4.209 & 12 & $0.85 \%$ & $1.63 \%$ \\
\hline Lithuania & 3.403 & 8 & $0.69 \%$ & $1.63 \%$ \\
\hline Latvia & 2.295 & 7 & $0.47 \%$ & $1.09 \%$ \\
\hline Slovenia & 2.003 & 6 & $0.41 \%$ & $0.95 \%$ \\
\hline Estonia & 1.345 & 6 & $0.27 \%$ & $0.82 \%$ \\
\hline Cyprus & 0.766 & 6 & $0.16 \%$ & $0.82 \%$ \\
\hline Luxemburg & 0.469 & 6 & $0.10 \%$ & $0.82 \%$ \\
\hline Malta & 0.405 & 5 & $0.08 \%$ & $0.68 \%$ \\
\hline Total & 492.975 & 736 & $100 \%$ & $100 \%$ \\
\hline
\end{tabular}

Source: Cegiełka, Dniestrzański, Łyko, Misztal 2010a. 
Table 5. The proposed composition of the European Parliament in 2009-2014

\begin{tabular}{|c|c|c|c|c|c|}
\hline Member State & $\begin{array}{l}\text { Popula- } \\
\text { tion } \\
\text { (millions) }\end{array}$ & $\begin{array}{l}\text { Seats } \\
\text { in EP }\end{array}$ & $\begin{array}{c}\% \text { of } \\
\text { population } \\
\text { of EU }\end{array}$ & $\begin{array}{l}\% \text { of seats } \\
\text { in EP }\end{array}$ & $\begin{array}{c}\text { Population/MPs } \\
\text { (thousands) }\end{array}$ \\
\hline Germany & 82.438 & 96 & $16.72 \%$ & $12.80 \%$ & 858.73 \\
\hline France & 62.999 & 74 & $12.78 \%$ & $9.87 \%$ & 851.33 \\
\hline Great Britain & 60.393 & 73 & $12.25 \%$ & $9.73 \%$ & 827.30 \\
\hline Italy & 58.752 & 72 & $11.92 \%$ & $9.60 \%$ & 816.00 \\
\hline Spain & 43.758 & 54 & $8.88 \%$ & $7.20 \%$ & 810.34 \\
\hline Poland & 38.157 & 51 & $7.74 \%$ & $6.80 \%$ & 748.18 \\
\hline Romania & 21.610 & 33 & $4.38 \%$ & $4.40 \%$ & 654.86 \\
\hline Holland & 16.334 & 26 & $3.31 \%$ & $3.47 \%$ & 628.24 \\
\hline Greece & 11.125 & 22 & $2.26 \%$ & $2.93 \%$ & 505.69 \\
\hline Portugal & 10.570 & 22 & $2.14 \%$ & $2.93 \%$ & 480.44 \\
\hline Belgium & 10.511 & 22 & $2.13 \%$ & $2.93 \%$ & 477.79 \\
\hline Czech Republic & 10.251 & 22 & $2.08 \%$ & $2.93 \%$ & 465.96 \\
\hline Hungary & 10.077 & 22 & $2.04 \%$ & $2.93 \%$ & 458.03 \\
\hline Sweden & 9.048 & 20 & $1.84 \%$ & $2.67 \%$ & 452.39 \\
\hline Austria & 8.266 & 19 & $1.68 \%$ & $2.53 \%$ & 435.05 \\
\hline Bulgaria & 7.719 & 18 & $1.57 \%$ & $2.40 \%$ & 428.82 \\
\hline Denmark & 5.427 & 13 & $1.10 \%$ & $1.73 \%$ & 417.50 \\
\hline Slovakia & 5.389 & 13 & $1.09 \%$ & $1.73 \%$ & 414.56 \\
\hline Finland & 5.256 & 13 & $1.07 \%$ & $1.73 \%$ & 404.28 \\
\hline Ireland & 4.209 & 12 & $0.85 \%$ & $1.60 \%$ & 350.75 \\
\hline Lithuania & 3.403 & 12 & $0.69 \%$ & $1.60 \%$ & 283.61 \\
\hline Latvia & 2.295 & 9 & $0.47 \%$ & $1.20 \%$ & 254.95 \\
\hline Slovenia & 2.003 & 8 & $0.41 \%$ & $1.07 \%$ & 250.42 \\
\hline Estonia & 1.345 & 6 & $0.27 \%$ & $0.80 \%$ & 224.11 \\
\hline Cyprus & 0.766 & 6 & $0.16 \%$ & $0.80 \%$ & 127.74 \\
\hline Luxemburg & 0.469 & 6 & $0.10 \%$ & $0.80 \%$ & 78.18 \\
\hline Malta & 0.405 & 6 & $0.08 \%$ & $0.80 \%$ & 67.50 \\
\hline Total & 492.975 & 750 & $100 \%$ & $100 \%$ & - \\
\hline
\end{tabular}

Source: own elaboration based on (Cegiełka, Dniestrzański, Łyko, Misztal 2010). 


\section{The maximum over-representation degressively proportional distribution}

Let us introduce the following notations:

$M$ - number of seats in Parliament,

$n$ - number of states in the European Union,

$L-$ total population of the Union,

$l$ - the smallest population of the state (now Malta).

Here, over-representation of the least populous country of the European Union is understood by dividing the number of seats gained by it by the principle of degressive proportionality, and the theoretical number of seats, if the ordinary proportionality was in force. For simplicity we do not include here roundings resulting from the fact that the number of seats is an integer. According to the principle of fair distribution, in an extreme case, all the EU countries could achieve a similar number of seats. Therefore, the maximum theoretical overrepresentation of Malta is:

$$
S=\frac{\frac{M}{n}}{\frac{M l}{L}}=\frac{L}{n l} .
$$

Currently, $L \approx 500 \mathrm{~m}, l \approx 0.41 \mathrm{~m}, n=27$, so $S \approx 500 / 11 \approx 45.4$.

\section{Summary}

In the case of degressive proportionality, the large over-representation of small countries is a deliberate concession of larger countries to ensure that less populated states are adequately represented (the principle of European solidarity). It is worth emphasizing how important the role played by election thresholds is, which prevents the excessive fragmentation of the parliament. Thus they act as a stabilizing factor in the political scene, which in Polish conditions cannot be overestimated. The weakness of the thresholds is the fact that they distort the proportionality of the results and cause the over-representation of certain parties. In extreme cases, this can lead to the dictatorship of one party, even if it is provided with the low popular support. 


\section{References}

Banaszak B., Preisner A. (1992). Wprowadzenie do prawa konstytucyjnego. Wydawnictwo Uniwersytetu Wrocławskiego. Wrocław.

Cegiełka K., Dniestrzański P., Łyko J., Misztal A. (2010a). Division of Seats in the European Parliament. Journal for Perspectives of Economic Political and Social Integration. Vol. 16. No 1-2. Towarzystwo Naukowe KUL. Lublin. Pp. 39-56.

Cegiełka K., Dniestrzański P., Łyko J., Misztal A. (2010b). Proporcjonalne sposoby podziału, czyli jak podzielić to, co niepodzielne. W: Osiagnięcia i perspektywy modelowania i prognozowania zjawisk społeczno-gospodarczych. PN Uniwersytetu Ekonomicznego w Krakowie. Kraków. Pp. 46-56.

Gallagher M. (1991). Proportionality, Disproportionality and Electoral Systems. Electoral Studies 10. Pp. 33-51.

Haman J. (2000). Racjonalne metody podziału mandatów $w$ wyborach proporcjonalnych. Studia Socjologiczne 1-2. Warszawa. Pp. 14-47.

Kamiński M., Gryz J. (1997). Koalicje wyborcze: Lekcja 1993 roku. W: J. Wasilewski (red.). Zbiorowi aktorzy polskiej polityki. ISP PAN. Warszawa.

Lamassoure A., Severin A. (2007). Sprawozdanie w sprawie sktadu Parlamentu Europejskiego. A6-0351/2007.

Lijphart A. (2000). Electoral Systems and Party Systems. A Study of Twenty Seven Democracies, 1945-1990. Oxford University Press. New York.

Ordynacja (1991). Ordynacja Wyborcza do Sejmu Rzeczypospolitej Polskiej. Dziennik Ustaw RP nr 59/1991.

Ordynacja (2007). Ordynacja Wyborcza do Sejmu Rzeczypospolitej Polskiej. Dziennik Ustaw RP nr 190/2007.

Rae D.W., Hanby V., Loosenmore J. (1971). Threshold of Representation and Threshold of Exclusion: An Analytic Note of Electoral Systems. Comparative Political Studies 3.

Sosnowski Ł. (2008). Nowy podzial mandatów do Parlamentu Europejskiego. Biuletyn Analiz UKIE. Nr 20.

Taagepera R. (1998). Effective magnitude and effective threshold. Electoral Studies 17. Pp. 393-404. 